\title{
ONLINE TRAINING FOR FACE RECOGNITION SYSTEM USING IMPROVED PCA
}

\author{
Widodo Budiharto \\ Informatics Engineering Dept., School of Computer Science, BINUS University \\ J1. K.H. Syahdan No. 9, Palmerah, Jakarta Barat 11480 \\ widodo@widodo.com
}

\begin{abstract}
The variation in illumination is one of the main challenging problem for face recognition. It has been proven that in face recognition, differences caused by illumination variations are more significant than differences between individuals. Recognizing face reliably across changes in pose and illumination using PCA has proved to be a much harder problem because eigenfaces method comparing the intensity of the pixel. To solve this problem, this research proposes an online face recognition system using improved PCA for a service robot in indoor environment based on stereo vision. Tested images are improved by generating random values for varying the intensity of face images. A program for online training is also developed where the tested images are captured real-time from camera. Varying illumination in tested images will increase the accuracy using ITS face database which its accuracy is $95.5 \%$, higher than ATT face database's as $95.4 \%$ and Indian face database's as 72\%. The results from this experiment are still evaluated to be improved in the future.
\end{abstract}

Keywords: face recognition, illumination, improved PCA, service robot, ITS face database

\begin{abstract}
ABSTRAK
Variasi iluminasi merupakan salah satu tantangan utama dalam pengenalan wajah. Telah terbukti perbedaan karena variasi iluminasi lebih penting dibandingkan perbedaan pada tiap wajah individu. Pengenalan wajah terhadap perubahan pose dan iluminasi menggunakan PCA terbukti lebih susah karena methode eigenspace yang digunakan membandingkan intensitas dari tiap piksel. Untuk mengatasi masalah ini, penelitian ini mengusulkan sistem pengenalan wajah online menggunakan PCA yang diperbaharui untuk digunakan pada service robot pada lingkungan indoor berbasiskan stereo vision. Improvisasi dilakukan dimana gambar yang ada diberikan nilai random untuk intensitasnya. Kemudian dibangun program pelatihan online dimana gambar yang diujicobakan diperoleh secara real-time dari kamera. Memvariasikan iluminasi pada image pelatihan akan meningkatkan akurasi dengan metode ITS face database yang memiliki akurasi 95.5\%, lebih tinggi dibandingkan ATT face database sebesar 95.4\% dan Indian face database $72 \%$. Hasil eksperimen ini masih dievaluasi untuk perbaikan di masa mendatang.
\end{abstract}

Kata kunci: pengenalan wajah, iluminasi, PCA terbaharui, service robot, ITS face database 


\section{INTRODUCTION}

Ability for face recognition and real interaction with a user is one important issue for developing vision-based service robots. Since face tracking and face recognition are essential functions for a service robot, many researchers developes face-tracking mechanism for the robot (Yang M., 2002) and face recognition system for service robot (Budiharto, W., 2010). The objective of this chapter is to propose an online training for face recognition system using improved principal component analysis (PCA) which is implemented to a service robot in a dynamic environment using stereo vision.

Variation in illumination is a challenging problem for face recognition. It has been proved that differences caused by illumination variations are more significant than ones between individuals (Adini et al., 1997). Recognizing face reliably across changes in pose and illumination using PCA is proved to be a much harder problem because of eigenfaces method compared to the intensity of the pixel. To solve this problem, we have improved the training images by generating random values for varying the intensity of face images.

We have proposed an online face recognition system using PCA. This model is very important because it can be implemented to service robots so that they are able to automatically learn and recognize the customers. Several experiments using three poses images (front, left and right) of each person and given training images with varying illumination improves the success rate for recognition. Our proposed method is successfully implemented to a service robot called Srikandi III in our laboratory.

\section{Literature Study}

\section{Improved Face Recognition Using PCA}

Face is our primary focus of attention in developing a vision-based service robot. Unfortunatelly, developing a computational model of face recognition is quite difficult, because faces are complex and multidimensional. Modelling of face images can be based on a statistical model like principal component analysis (PCA) (Turk and Pentland, 1991 ) and linear discriminant analysis (LDA) (Etemad \& Chellappa, 1997; Belhumeur et.al, 1997), as well as on a physical model on the assumption of certain surface reflectance properties, such as Lambertian surface (Zoue et al., 2007). Linear discriminant analysis (LDA) is a method for finding such a linear combination of variables which best separates two or more classes. Constrasting their PCA which encoded information in an orthogonal linear space, LDA which is also known as fischerfaces method encodes discriminatory information in a linear separable space of which bases are not necessary orthogonal. However, the LDA result is mostly used as a part of a linear classifier (Zhao et al., 1998).

PCA is a standard statistical method for feature extraction by reducing the dimension of input data by a linear projection that maximizes the scatter of all project samples. The scheme is based on an information theory approach that decomposes face images into a small set of characteristic feature images called "eigenfaces", a principal component of the initial training set of face images. Recognition is performed by projecting a new image into the subspace spanned by the eigenfaces called "face space", and then classifying the face by comparing its position in face space with the positions of known individuals. PCA based approaches typically include two phases: training and classification. In the training phase, an eignespace is established from the training samples using PCA and the training face images are mapped to the eigenspace for classification. In the classification phase, an input face is projected to the same eignespace and classified by an appropriate classifier (Turk \& Pentland, 1991 ). Let a face image I (x,y) be a two-dimensional $N$ by $N$ array of (8-bit) 
intensity values. An image may also be considered as a vector of dimension $\mathrm{N}^{2}$, so that a typical image of size 256 by 256 becomes a vector of dimension 65,536 ( a point in 65,536-dimensional space). If $\Phi$ is face images and $\mathrm{M}$ is training set face images, we can compute the eigenspace $u_{i}$ as below:

$$
u_{i}=\sum_{k=1}^{M} v_{i k} \Phi_{k}
$$

Where $u_{i}$ and $v_{i k}$ are the $i^{\text {th }}$ eigenspace and the $k^{\text {th }}$ value of the $i^{\text {th }}$ eigenvector. Then, we can determine which face class provides the best description of an input face images to find the face class $k$ by using the euclidian distance $\varepsilon_{\mathrm{k}}$ between the new face projection $\Omega$, the class projection $\Omega_{\mathrm{k}}$ and threshold $\theta$ using the formula below:

The stereo camera used in this research is $640 \times 480$ pixels. The size of face image is cropped to $92 \times 112$ pixels using region of interest method (ROI) as shown in Figure 1. These images are also used as training images for face recognition system. We use histogram equalization for contrast adjustment using the image's histogram. This method usually increases the global contrast of many images, especially when the usable data of the image is represented by close contrast values. Through this adjustment, the intensity can be better distributed on the histogram. This allows for areas of lower local contrast to gain a higher contrast. Histogram equalization accomplishes this by effectively spreading out the most frequent intensity values.

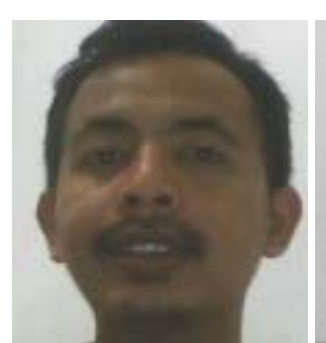

(a)

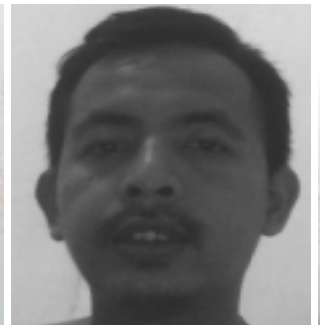

(b)

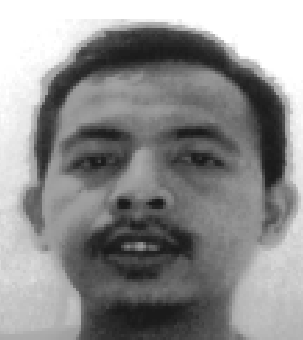

(c)

Figure 1. Image preprocessing from original image (a), to greyscaled image (b) and made to histogram equalization (c).

Practical face recognition system needs to deal with the illumination variation which is a main challenging problem. Various methods have been proposed to solve the problem, such as: face and illumination modeling, illumination invariant feature extraction and preprocessing and normalization. In Belhumeur and Kriegman's (1998), an illumination cone is proposed for the first time. It is proved that the set of $n$-pixel images of a convex object with a Lambertian reflectance function, under an arbitrary number of point light sources at infinity, form a convex polyhedral cone in IRn called "illumination cone" (Belhumeur \& Kriegman 1998). In this research, we construct images under different illumination conditions by generating random values for brightness level developed using Visual $\mathrm{C}++$ technical Pack by this formula:

Where $f_{o}$ is the intensity value after the brightness operation applied and $f_{1}$ is the intensity value before brightness operation apllied and is the brightness level. The effect of brightness level is shown at histrogram below (Figure 2): 

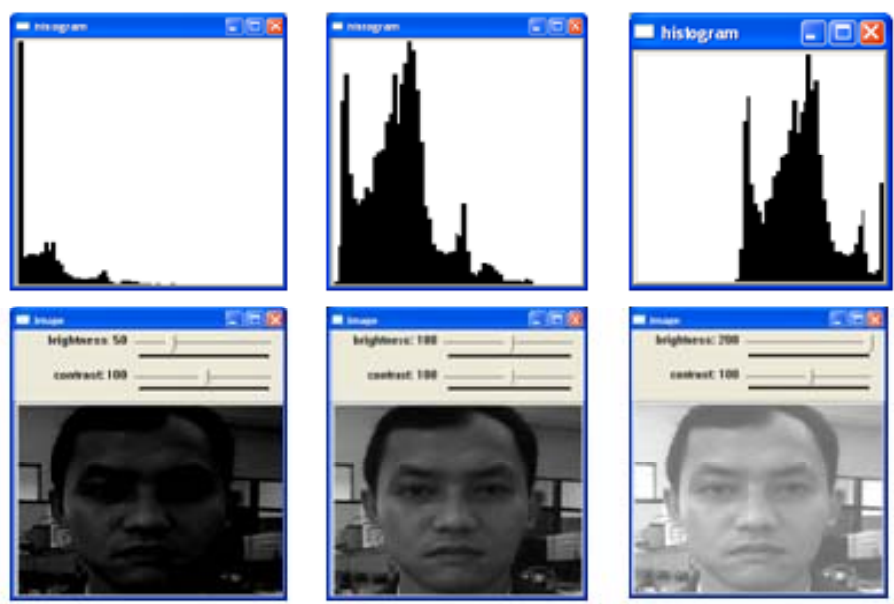

Figure 2. Effects of varying the illumination for a face.

For storing user's training faces, we propose a simple face table database (face_id, name, date_registered, image_file1, image_file2, image_file3) as shown in Figure 3:

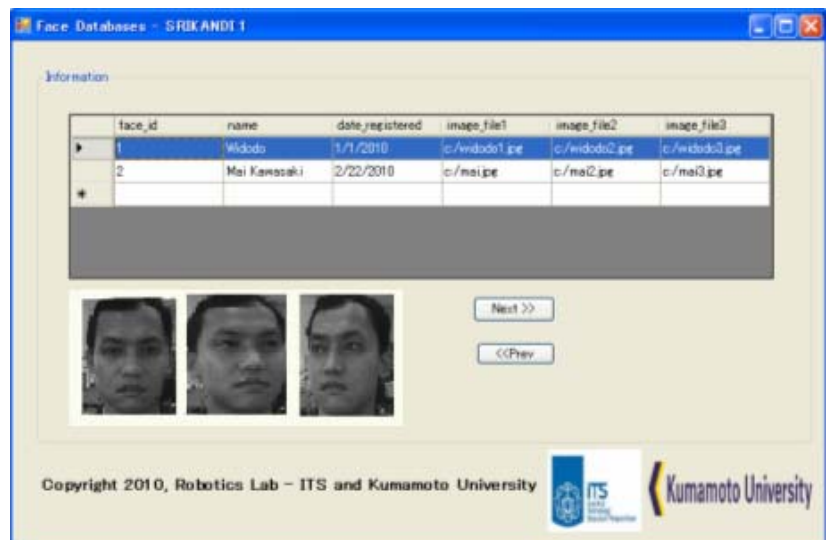

Figure 3. Proposed face databases using 1 table, 3 images for each person (front, left and right side).

\section{METHOD}

We have developed a method for online training for face recognition system. The training images with extention .pgm is stored in a directory. In online mode, the program will store the face images to files. In training mode, the training images will be executed for training. In testing mode, the input image from camera will be compared with the training images. The algorithm is shown below:

Algorithm 1. Online training for Face recognition system using imporved PCA.

\section{Begin}

Call onlineTraining

If customer_identified $==$ true then

Display name and confident

Else 


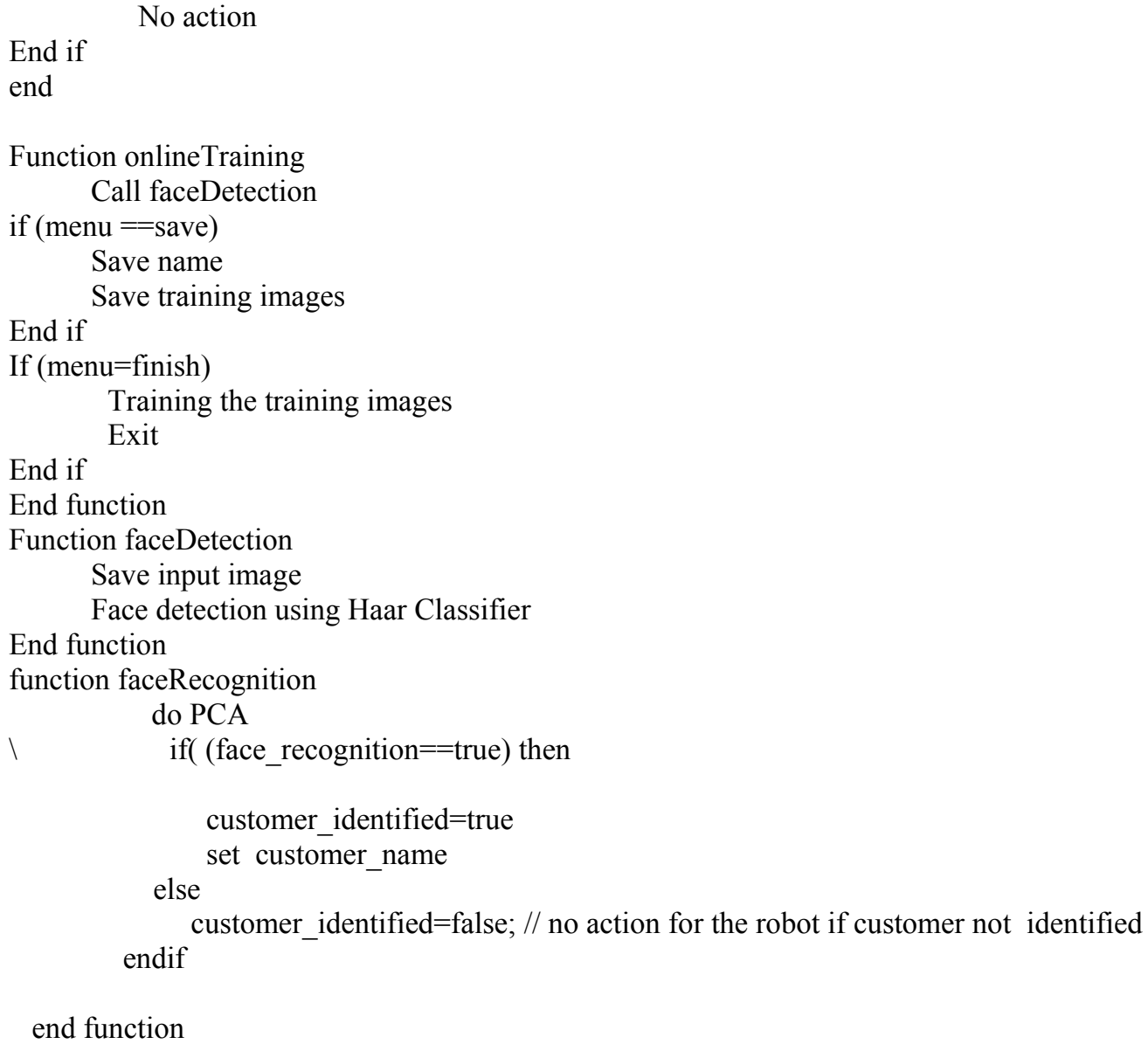

end function

We have developed a vision-based service robot called Srikandi III with the ability to perform face recognition and avoid people as moving obstacles. This wheeled robot is the next generation of Srikandi II (Budiharto, 2010). The prototype of service Robot Srikandi III utilizing a low cost stereo Minoru 3D camera is shown in Figure 4:

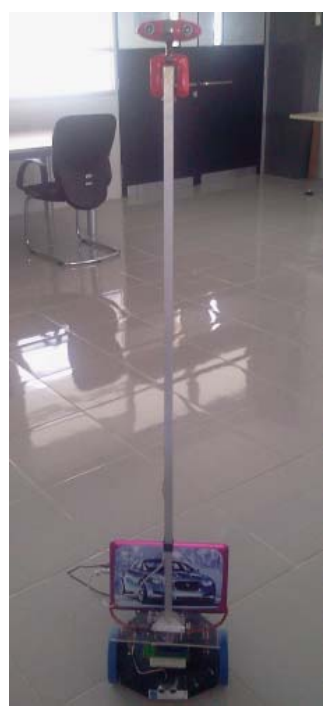

Figure 4. Prototype of service robot Srikandi III using stereo vision. 


\section{RESULTS AND DISCUSSION}

We have identified the effect of varying illumination to the recognition accuracy for our database called ITS face database as shown in Table 1. Results shows that by giving enough training images with variation of illumination generated randomly, the success rate of face recognition will be improved. If the recoqnition test does not apply illumination varying, and enough training images are available, PCA can recognize people's faces with success rate up to $100 \%$. But if varying illumination is applied and the training images are not sufficient (for example six tested images with only six training images) the success rate only $50 \%$. However, if the number of training images are increased, the success rate can reach $100 \%$. Based on Table 1 , too many tested images with varied illumination will decrease the success rate from $100 \%$ to $91.60 \%$ because the training images are not adequate to recognize the variation of illumination from tested images. Therefore, the best way to increase the succes rate with many tested images with illumination variation is have adequate number of training images.

Table 1

Tested images without and with Illumination Variation

\begin{tabular}{ccc}
\hline \multicolumn{1}{c}{ Training images } & Tested images & Success rate \\
\hline \multicolumn{2}{c}{ No varying illumination } \\
\hline 6 & 6 & $100 \%$ \\
12 & 6 & $100 \%$ \\
24 & 6 & $100 \%$ \\
\hline \multicolumn{3}{c}{ Varying Illumination } \\
12 & 6 & $50.00 \%$ \\
24 & 6 & $66.00 \%$ \\
24 & 6 & $100 \%$ \\
\hline
\end{tabular}

We also evaluate the result of our proposed face recognition system and compared with ATT and Indian face database using Face Recognition Evaluator developed by Matlab. Each face database consists of ten sets of people's face. Each set of ITS face database consists of 3 poses (front, left, right side) and varied with illumination. ATT face database consists of nine differential facial expression and small occlusion (by glass) without variation of illumination. The Indian face database consists of eleven pose orientations without variation of illumination and the size of each image is too small than one of ITS and ATT face database. The success rate comparison among the three face databases is shown in Figure 5. From the figure it is clearly noticed that ITS database have highest accuracy than ATT and Indian face database when the illumination of the tested images is varied. The accuracy using PCA in ITS face database as much as $95.5 \%$, higher than ATT face database as $95.4 \%$ and IFD face database as $72 \%$.

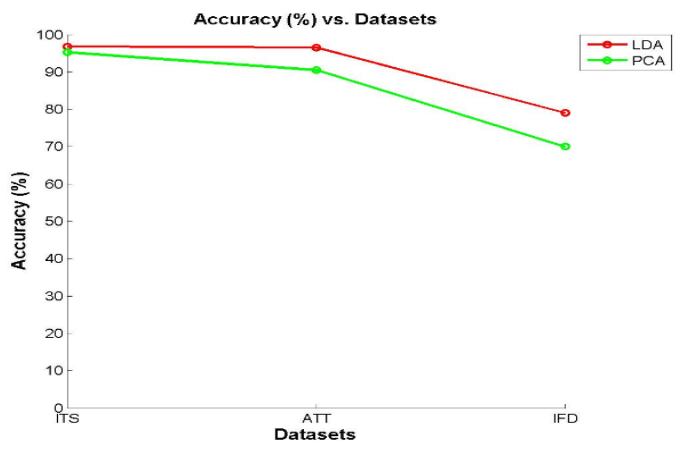

Figure 5. Face recognition accuracy of the 3 face databases (each uses 10 face sets). 
For total execution time (Figure 6), it is noticed that the Indian face database (IFD) takes the shortest because the size of each image is lowest then others stored in ITS and ATT face database. Figure 7 below shows the duration of training time used for ITS and ATT faces database. Because ITS and ATT have the same size for each image, they have the same values for training time compared to Indian face database.

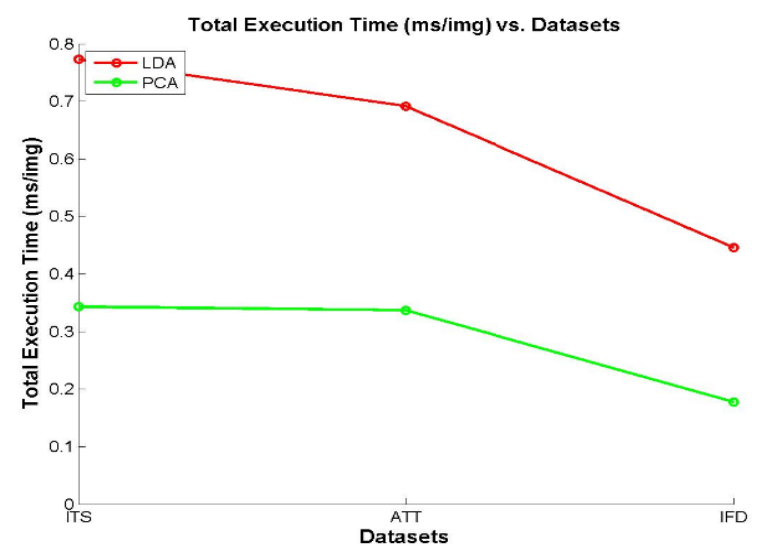

Figure 6. Total execution time for ITS, ATT and IFD.

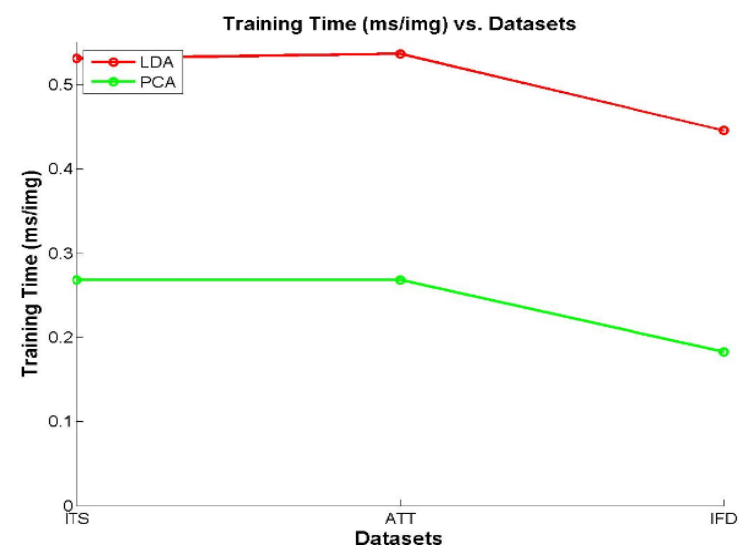

Figure 7. Training time for ITS, ATT and IFD.

The online training for face recognition system succesfully identified user's face as displayed in Figure 8. This information is stored in .xml file.

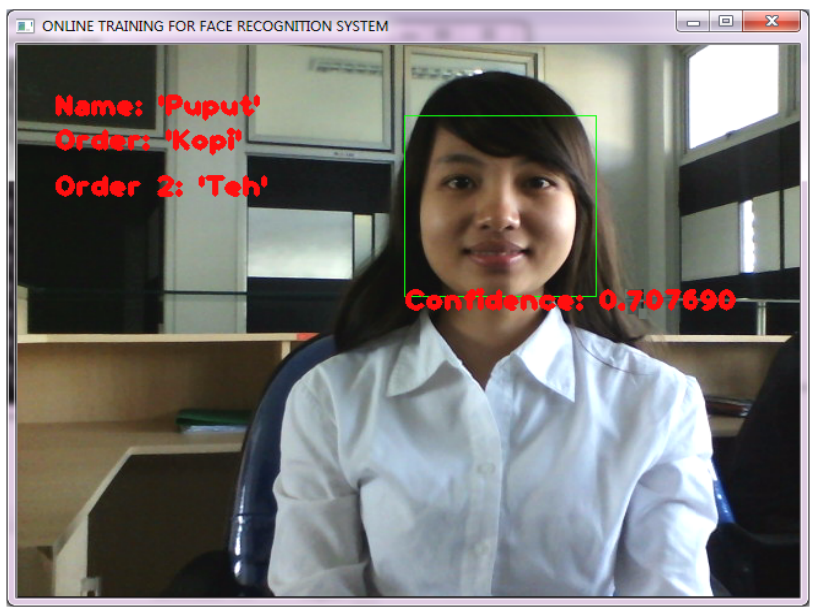

Figure 8. Result of our online training for face recognition system. The program succesfully identified customer and other information.

\section{CONCLUSION}

This article presents an online training for face recognition system using improved PCA. This system is implemented to a service robot in dynamic environment using stereo vision. From the results it is proved that varying illumination in training images will increase the success rate in face recognition. The accuracy test uses our proposed method ITS face database which generates $95.5 \%$ accuracy, a bit higher than ATT face database does as $95.4 \%$ and Indian face database does as $72 \%$. 
An adequate number of tested images with illumination variation is required to make sure the process of recognition is accurate. The simple face database system proposed can be used for the visionbased service robot. The experiment results with various situations show that the proposed methods and algorithms work well together. We hope this system can be improved and implemented for any vision-based service robot. In future work, we will implement this system and develop a vision-based humanoid service robot for serving customers at Cafe/Restaurants.

\section{REFERENCES}

Adini, Y.; Moses, Y. \& Ulman, S. (1997). Face Recognition: The Problem Of Compensating for Changes in Illumination Direction. IEEE Transactions Pattern Analysis and Machine Intelligence,19 (7), 721-732.

Belhumeur, P., Kriegman, D. (1998). What is the set of images of an object under all possible illumination conditions. International Journal of Computer Vision, 28 (3), 245-260.

Etemad, K., Chellappa R (1997). Discriminant Analysis for Recognition of Human Face Images. Journal of the Optical Society of America, 14 (8), 1724-1733.

Turk M. and Pentland A. (1991). Face Recognition Using Eigenfaces. Proceeding of IEEE Conference on Computer Vision and Pattern Recognition, 586-591.

Yang, M. (2000). Detecting Faces Images: A Survey. IEEE Transactions on Pattern Analysis and Machine Inteligence, 24 (1), 34-58. 